\title{
Inhibition of HIV-1 Protease by Carpobrotus edulis (L.)
}

\author{
Beauty E. Omoruyi $\mathbb{D}^{1},{ }^{1}$ David I. Ighodaro, ${ }^{2}$ Anthony J. Afolayan $\mathbb{D}^{\circ},{ }^{3}$ and Graeme Bradley $\mathbb{D I}^{4}$ \\ ${ }^{1}$ Applied Microbial and Health Biotechnology Institute, Cape Peninsula University of Technology, P.O. Box 1906, Bellville 7535, \\ Cape Town, South Africa \\ ${ }^{2}$ Department of Agricultural Extension, Cape Peninsula University of Technology, P.O. Box 1906, Bellville 7535, \\ Cape Town, South Africa \\ ${ }^{3}$ Medicinal Plant and Economic Development Research Centre, Department of Botany, University of Fort Hare, \\ Private Bag X1314, Alice 5700, South Africa \\ ${ }^{4}$ Department of Biochemistry and Microbiology, University of Fort Hare, Private Bag X1314, Alice 5700, South Africa
}

Correspondence should be addressed to Graeme Bradley; gbradley@ufh.ac.za

Received 27 February 2020; Revised 7 May 2020; Accepted 19 May 2020; Published 8 June 2020

Guest Editor: Yuan Xu

Copyright (c) 2020 Beauty E. Omoruyi et al. This is an open access article distributed under the Creative Commons Attribution License, which permits unrestricted use, distribution, and reproduction in any medium, provided the original work is properly cited.

\begin{abstract}
Carpobrotus edulis (L.) is a plant commonly found in the Eastern Cape Province of South Africa and is used for the general treatment of infections relating to the human immunodeficiency virus (HIV). HIV-1 protease plays an important role during HIV replication and maturation to its infectious form, and therefore inhibition of the enzyme is one of the main focus areas in drug development. The inhibitory effect of a water extract of C. edulis leaves against HIV-1 protease activity was determined using the SensoLyte ${ }^{\circledR} 520$ HIV-1 protease assay fluorimetric kit and employing a HiLyte Fluor ${ }^{\mathrm{TM}} 488 / \mathrm{QXL}^{\mathrm{TM}} 520$ fluorescence resonance energy transfer (FRET) peptide. Cytotoxicity of the extract towards HeLa Chang cell lines was determined using an in vitro MTT assay, and the phytochemical profile of the extract was determined with FT-IR and LC-MS. HIV-1 protease activity was inhibited $83.06 \%\left(\mathrm{IC}_{50} 1.6 \mathrm{mg} / \mathrm{ml}\right)(p<0.0001)$ by the pepstatin A inhibitor control. Treatment with all C. edulis extract concentrations $(16$, $1.6,0.16$, and $0.016 \mathrm{mg} / \mathrm{ml})$ inhibited HIV-1 protease activity significantly $(p<0.0001)$ in a typical dose response manner. With regards to cytotoxicity, the negative controls containing untreated $\mathrm{HeLa}$ Chang cells exhibited high formazan formation rates in contrast with the positive controls, containing curcumin, which reduced formazan formation significantly $(p<0.001)$, exhibiting cytotoxicity towards the cells. There was no significant $(p>0.05)$ difference in the formazan formation rates between the negative controls and $1,0.5,0.125,0.065,0.031$, and $0.015 \mathrm{mg} / \mathrm{ml}$ plant extract, confirming no toxicity of C. edulis extracts towards HeLa Chang cells. Major functional phytochemical compounds identified included alcohols, phenols, alkanes, amines, carboxylic acids, and esters. LC-ESI-TOF/MS analysis revealed the putative identities of main compounds present in the aqueous leaves extract, including some that contribute to its anti-HIV-1 protease action.
\end{abstract}

\section{Introduction}

The maturation of the human immunodeficiency virus (HIV) to its infectious form is dependent on the posttranslational cleavage of virus Gag (p55) and Gag-Pol (p160) structural proteins by HIV-1 protease [1]. HIV-1 protease is an aspartic protease with a molecular weight of $21.6 \mathrm{kDa}$. It is a dimeric enzyme composed of 99 amino acids residues of Asp25-Thr26-Gly27-Asp30 at the catalytic site [2]. The active site loops are held together by a network of hydrogen bonds between the active site amino acids and the surrounding residues [2]. Due to the strong hydrogenbonding forces between the Thr26 residues, the conformational core domain of the HIV-1 protease becomes very stable [3]. Amino acid residues of Gly27 accommodate and bind a substrate in a corresponding position in which the catalytic Asp25 carboxylate groups can attack the amide moiety of a substrate [4]. Also, the active site is covered by two extended beta-hairpins known as flap residues (lle47Gly48-Gly49-lle50), which bind firmly to other polyproteins of Phe-Pro, Pro-Tyr, and Leu-Phe, enhancing multiplicity of the virus [5]. Consequent to the manipulative cleavages of 
amino residues within the host cell protein, the virus thus complicates its initial recognition by $\mathrm{CD} 4$ receptors and T-cells [6].

Multimerization of polyproteins residues along with complex binding of the viral genomic RNA and other viral proteins in the host cell system gives rise to the formation of new virion particles [7]. The internalization of the newly formed virus is typically triggered by structural protein matrix A (MA), capsid (CA), and nucleocapsid (NC); this includes other spacer peptides $\mathrm{p} 1, \mathrm{p} 2$, and $\mathrm{p} 6$ at the virus catalytic site [8]. During the late phase of the virus fusion, the myristoylated N-terminal MA protein directs Gag-Pol towards the plasma membrane, where the NC proteins associate with the viral genome to act as a localization signal. Budding of the virion is formed through the assembly of several thousand copies of Gag lipid molecules in the host cell plasma membrane [9]. This process is finally completed when the spherical mature virion pinches off the inner side of the plasma membrane and carries its viral cargo, together with some extracellular fluid to its intracellular destination [10]. Alteration of HIV-1 protease activity using inhibitors has led to the deactivation of viral particles and reduced infectivity [11]. Without HIV-1 protease, the polyproteins would not be able to cleave into functional products and ultimately would not produce viruses from a host cell nor cause any infection. Therefore, due to the fundamental importance of HIV-1 protease for the realization of HIV, it has become the main target in the development of anti-HIV drug therapy [7].

HIV-1 protease inhibitors (Pls) approved by the United States Food and Drug Administration (US FDA) [12] include saquinavir, amprenavir, nelfinavir, indinavir, ritonavir, lopinavir, tipranavir, fosamprenavir, and darunavir $[13,14]$. These inhibitors are substrate-based hydroxyethylamines that target the enzyme complex sites [15]. They are made up of an amino acid sequence of Serine-LucineAsparagine-Phenylalanine-Psi $\quad\left(\mathrm{CH}(\mathrm{OH})-\mathrm{CH}_{2} \mathrm{~N}\right.$-ProlineIsoleucine-Methyl-LValinate, which binds the acetyl group $\left(\mathrm{C}_{2} \mathrm{H}_{4} \mathrm{O}\right)$ of HIV-1 protease [16]. Antiviral protease inhibitors mimic endogenous peptides by binding to the active site of HIV aspartyl protease, thereby preventing the cleavage of viral polyprotein precursors into mature functional proteins that replicate viral load $[16,17]$. Combination of Pls with other inhibitors (e.g., the highly active antiretroviral therapy, HAART) with different mechanisms of action has led to a significant decline in HIV-1-associated morbidity and mortality $[7,18]$. Long-term administration of HAART containing protease inhibitor has resulted in unpredicted adverse effects including hyperbilirubinaemia, insulin resistance, diabetes, and hyperlipidaemia [19]. Combinations of Pls without HAART could also have several detrimental side effects. Tipranavir co-administered with $200 \mathrm{mg}$ of ritonavir led to (i) intracerebral hemorrhagic stroke, a devastating event that stems from the rupture of blood vessels in the brain, with the subsequent accumulation of blood in the parenchyma [20], and (ii) serious clinical hepatitis and hepatic infection [20-22]. Other side effects of Pls drugs are associated with diarrhea, nausea, rash, fever, fatigue, vomiting, abdominal pain, headache, bronchitis, depression, asthenia, insomnia, cough, diabetes mellitus, increased lipid levels, and changes in body fat levels [23]. The negative health effects of certain PIs and combinations thereof have led to an increased interest in alternative sources of antiprotease inhibitors.

Carpobrotus edulis (L.) belongs to the family of Aizoaceae, subfamily of Mesembryanthemaceae. The herb is indigenous to South Africa, and it is mostly found in the Eastern Cape Province, Northern Cape, KwaZulu-Natal, Free State, and Western Cape. It bears some common native names, including igukuma (Isixhosa), ikhambi-lamabulwoumgongozi (IsiZulu), suurvy-rankvy-vyerank (Afrikaans), and freeway ice-plant (English) [24]. It is also commonly referred to as "Triple E," i.e., "excellent edible evergreen" herb. Carpobrotus edulis (L.) is a perennial dense matforming herb with succulent leaves. The herb is resistant to drought and wind conditions and can be planted on flat, sandy ground and on loose sand dunes, gardens, lime-rich, brackish soils as well as in containers, rockeries, and embankments. The fruits can be eaten fresh, though they have a strong astringent, salty, and sour taste [25]. Local communities in the Eastern Cape Province traditionally use the herb's leaves as a remedy known to treat several infections including tuberculosis (TB), dysentery, diabetes, sore throat, and mouth infections. The roots and leaves are boiled in water or alcohol for 30-45 min, and approximately 5-125 ml was administered to adults and children depending on age and the severity of the illness. Leave extract powder is also prepared and used to treat burns, bruises, scrapes, cuts, ringworm, eczema, dermatitis, rash, and cracked lips. A mixture of leave, olive oil, and honey is used for the treatment of laryngitis and TB [26]. Previous studies have demonstrated the potential inhibitory effect of C. edulis extracts against several opportunistic infections common to HIV/AIDS [27-29]. The main phytochemical compounds found in hexane, acetone, and ethanol extracts, as determined with GC/MS, include monoterpenes, sesquiterpenes, diterpenes, phytol, and fatty acids with their methyl esters. These compounds were found to have high antioxidant, antifungal, and antimicrobial activities [27-29].

The present study evaluated the inhibitory effect of a water extract of $C$. edulis leaves against HIV-1 protease activity by utilizing a Hilyte Fluor ${ }^{\mathrm{TM}} 488 / \mathrm{QXL}^{\mathrm{TM}} 520$ fluorescence resonance energy transfer (FRET) peptide as substrate. Cytotoxicity of the extract towards HeLa Chang cells was evaluated and the phytochemical profile determined with FT-IR and LC-MS.

\section{Materials and Methods}

2.1. Chemicals. Acetonitrile, formic acid, DMSO, and EDTA were purchased from Merck (Darmstadt, Germany); 3-(4,5dimethylthiazol-2-yl)-2,5-diphenyl tetrazolium bromide (MTT) was purchased from Thermo Fisher Scientific (Cat no. M6494, AEC-Amersham SOC Ltd., South Africa); and curcumin (Cat no. C1386-5G) and potassium bromide (FTIR grade; Cat no. 221864) were purchased from SigmaAldrich (Merck, Darmstadt, Germany). Water was 
successively purified by reverse osmosis followed by Milli-Q water purification (Millipore, Massachusetts, USA).

2.2. Collection of Plant Material. Carpobrotus edulis (L.) leaves were collected during late winter in August 2012 in the Nkonkobe Municipality district of the Eastern Cape Province of South Africa. The identity was confirmed by Prof. Grieson of the Department of Botany, University of Fort Hare (UFH), Alice, South Africa. A voucher specimen of the plant was preserved as "Omo 2012/1-Omo 2012/20" at the UFH herbarium. Leave samples were washed with distilled water, air-dried at room temperature for 14 days, and ground into a powder using a Romer Series II Grinding mill (Romer Labs, Newark, Delaware, USA).

2.3. Preparation of Plant Extract. Dried powdered leaves $(100 \mathrm{~g})$ were extracted with $1 \mathrm{~L}$ boiled distilled water on a mechanical shaker (Stuart Scientific Orbital Sharker 20.2, SOSI, Essex, UK) for $12 \mathrm{~h}$. The extract was filtered through Whatman No 4 filter paper (Merck, Darmstadt, Germany) and the filtrate was refiltered with Whatman No 1 filter paper. The final filtrate was freeze-dried, yielding $6.2 \mathrm{~g}$ dried extract, and stored desiccated at $4^{\circ} \mathrm{C}$ prior to use. Stock solutions of $16,1.6,0.16$, and $0.016 \mathrm{mg} / \mathrm{ml}$ were prepared in distilled water and used in experiments evaluating the inhibition of HIV-1 protease activity. A stock solution of $2 \mathrm{mg} /$ $\mathrm{ml}$ was prepared in distilled water, and two-fold serial dilutions were prepared in Dulbecco's minimum essential medium (DMEM; Cat no. 11960069, Thermo Fisher Scientific, AEC-Amersham SOC Ltd., South Africa) to obtain working solutions of $1,0.5,0.25,0.125,0.062,0.031$, and $0.015 \mathrm{mg} / \mathrm{ml}$, which were used to evaluate the cytotoxic properties of the plant extract.

2.4. HIV-1 Protease Activity Assay. HIV-1 protease activity was determined according to the method of AnaSpec, Fremont, California, USA, utilizing the SensoLyte ${ }^{\circledR} 520$ HIV-1 protease fluorimetric assay kit (Cat no. AS-71147, AnaSpec, Fremont, California, USA) and black, flat-bottom 96-well microplates with nonbinding surfaces (Cat no. CLS3600, Merck, Darmstadt, Germany). Assay working solutions were freshly prepared by following the instructions with regards to the enzyme assay buffer, active recombinant HIV-1 protease stock solution $(0.2 \mathrm{mg} / \mathrm{ml}$; Cat no. $72028-5$, AnaSpec, Fremont, California, USA), HIV-1 fluorescence resonance energy transfer (FRET) substrate, and the reference aspartic acid protease (pepstatin A) inhibitor.

2.4.1. Optimization of HIV-1 Protease Activity. In order to determine the optimal enzyme activity response, the following HIV-1 protease combinations were evaluated: (i) 800 -fold diluted HIV-1 protease stock in 1x enzyme buffer $(40 \mu \mathrm{l})$ and nuclease-free water $(10 \mu \mathrm{l})$, (ii) 80 -fold diluted HIV-1 protease stock in $1 \mathrm{x}$ enzyme buffer $(40 \mu \mathrm{l})$ and nuclease-free water $(10 \mu \mathrm{l})$, and (iii) to evaluate the effect of the inhibitor, water was replaced with pepstatin A solution $(10 \mu \mathrm{l})$ in each reaction combination.

The enzymatic reactions were initiated by adding HIV-1 protease FRET substrate solution $(50 \mu \mathrm{l})$ and plates incubated at $25^{\circ} \mathrm{C}$ for $15 \mathrm{~min}$. Reactions were performed in triplicate. The fluorescence intensity of the HIV-1 protease activity was measured at an excitation (Ex) wavelength of $490 \mathrm{~nm}$ and emission (Em) wavelength of $520 \mathrm{~nm}$ in minute intervals for 60 min using a fluorescence kinetic synergy MX analytical diagnostic reader (Gen spectrophotometer, Bio Tek, Vermont, USA). Data were transferred to a Microsoft Excel spreadsheet for further analysis. The average data generated were plotted against time.

\subsubsection{Determination of the Inhibitory Effect of the Plant} Extract on HIV-1 Protease Activity. The following reaction combinations were prepared: (i) 80-fold diluted HIV-1 protease stock in $1 \mathrm{x}$ enzyme buffer $(40 \mu \mathrm{l})$ and plant extract $(10 \mu \mathrm{l})$ from each concentration $(16,1.6,0.16$, and $0.016 \mathrm{mg} /$ $\mathrm{ml}$ ), respectively, (ii) positive controls containing 80-fold diluted HIV-1 protease stock in 1x enzyme buffer $(40 \mu \mathrm{l})$ and nuclease-free water $(10 \mu \mathrm{l})$, and (iii) inhibitor controls containing 80-fold diluted HIV-1 protease stock in $1 \mathrm{x}$ enzyme buffer $(40 \mu \mathrm{l})$ and pepstatin $\mathrm{A}(10 \mu \mathrm{l})$. The enzymatic reactions were initiated by adding $\mathrm{HIV}-1$ protease FRET peptide substrate solution $(50 \mu \mathrm{l})$ and plates incubated at $25^{\circ} \mathrm{C}$ for $15 \mathrm{~min}$. The reactions were performed in triplicate. Microplates were processed as described above. The percentage inhibition of each extract activity was calculated as

$$
\% \text { inhibition }=\frac{\mathrm{HIV}-1 \text { protease } \mathrm{Abs}-\mathrm{extract} \mathrm{Abs} / \text { positive control Abs }}{\mathrm{HIV}-1 \text { protease } \mathrm{Abs}} \times 100
$$

where Abs = absorbance. Graphs were generated by plotting inhibition percentage values against extract concentrations. The half maximal inhibitory concentration $\left(\mathrm{IC}_{50}\right)$ was calculated from the percentage values.

2.5. MTT Cytotoxicity Assay. The MTT cytotoxicity assay utilizing HeLa Chang cells was used to calorimetrically assess the effect of the plant extract on viable cell metabolic activity [30]. MTT, a yellow dye, is reduced by cellular enzymes to the purple product, formazan. The reduction of the dye is proportional to the density of viable cells. Assays were performed in triplicate.

2.5.1. Cell Line and Culture Medium. The HeLa Chang cell line used in this study was obtained from Prof. Van de Venter (Faculty of Medicine, Nelson Mandela Metropolitan 
University, South Africa). Cells were maintained in DMEM supplemented with $10 \%$ fetal bovine serum (Cat no. 16000044, Thermo Fisher Scientific, AEC-Amersham SOC Ltd., South Africa) and subcultured every two-three days [31]. At $80-90 \%$ confluence, cells were detached by adding Trypsin-EDTA solution $[0.25 \%$ trypsin $(\mathrm{w} / \mathrm{v})$ in $1 \mathrm{mM}$ EDTA, pH 7.4] and incubated for $3 \mathrm{~min}$ [32] at $37^{\circ} \mathrm{C}$ in a humidified incubator and $5 \% \mathrm{CO}_{2}$ (Standard Model Heracell $^{\mathrm{TM}}$ VIOS 250i, Cat no. 51030992, Thermo Fisher Scientific, AEC-Amersham SOC Ltd., South Africa).

2.5.2. MTT Cytotoxicity Assay. The cytotoxicity assays were conducted in 96-well microplates (Cat no. 6905A11, Thermo Scientific $^{\mathrm{TM}}$ Nunc $^{\mathrm{TM}}$, Thermo Fisher Scientific, AEC-Amersham SOC Ltd., South Africa) by seeding at a density of 2000 cells/well with $100 \mu \mathrm{l}$ of suspension. Cells were treated with $100 \mu \mathrm{l}$ of $1,0.5,0.25,0.125,0.062,0.031$, and $0.015 \mathrm{mg} / \mathrm{ml}$ plant extract in DMEM working solutions, respectively. The following control combinations were included: (i) negative controls containing DMEM $(100 \mu \mathrm{l})$ and (ii) positive control containing $0.1 \mathrm{mg} / \mathrm{ml}$ curcumin $(100 \mu \mathrm{l})$. The microplates were incubated for 24,48 , and $72 \mathrm{~h}$ as described above. Following incubation, the medium was removed by aspiration and replaced with DMEM $(100 \mu \mathrm{l})$ and MTT $(5 \mathrm{mg} / \mathrm{ml}$ in phosphate buffered saline, $\mathrm{pH} 7.4 ; 20 \mu \mathrm{l}$ ) and further incubated for $4 \mathrm{~h}$. Finally, the medium was aspirated and replaced with fresh DMSO $(100 \mu \mathrm{l})$ to solubilize the formazan crystals formed in the cells. The absorbance was measured at $570 \mathrm{~nm}$ with a fluorescence kinetic synergy MX analytical diagnostic reader (Gen spectrophotometer, Bio Tek, Vermont, USA).

2.6. Statistical Analysis. The NCSS 2019 software was used for statistical analysis [33]. Data were subjected to natural $\log (\ln )$ transformation of all variables and analysed within a generalised linear model ANOVA. Multiple comparisons were analysed using the Tukey-Kramer multiple comparison procedure. This method provides joint simultaneous confidence intervals for all pairwise differences between the means and also provides the multiple comparison $p$ value. Generally, $p<0.05$ was used as statistical significance. In addition, the size of the F-ratios was used to measure relative sizes of differences.

2.7. Determination of the Phytochemical Profile with FT-IR Spectroscopy. Fourier-transform infrared (FT-IR) spectrophotometry is one of the most important analytical techniques used for identifying organic and inorganic chemical compounds and functional groups in plant samples. It can provide a snapshot of any metabolic composition of a tissue at a given time by measuring the infrared radiation of bonds within chemical functional groups and generating a spectrum that can be regarded as a biochemical fingerprint of the sample [34].

The C. edulis powdered water extract was analysed for characteristic functional groups using FT-IR spectrophotometry (Perkin Elmer Spectrum Series Model-2000, Japan).
In brief, powdered extract $(2 \mathrm{mg})$ and potassium bromide $(2.5 \mathrm{mg})$ were homogenized using a mortar and pestle. A portion of the homogenized mixture was placed onto the FT-IR loading disc, pressed with a mini hand press to form a thin film of potassium bromide, and loaded into the FT-IR spectrophotometer with the scan range set at 4000 to $500 \mathrm{~cm}^{-1}$ and resolution at $4 \mathrm{~cm}^{-1}$. Identification of functional groups was analysed using the reference standard absorption peak which corresponds to bonds in the infrared region [34].

2.8. Identification of the Extracted Compounds with LC-MS. Liquid chromatography coupled to a mass spectrometer detector (LC-MS) was performed according to the methods of Akinrinde et al. [31], using a high performance Agilent 1260 Infinity Liquid Chromatography (LC) system, equipped with an Ab Sciex 5600 Triple TOF hybrid mass spectrometer (Applied Biosystems (AB) SCIEX, Framingham, MA, USA). The 5600 AB SCIEX Triple TOF has high selectivity and sensitivity accuracy $(<5 \mathrm{ppm})$ that quantify and identify large panels of analytes across different compound classes in a single scan. This has made it valuable for small molecule analysis throughout the world [31]. Plant extract $(2 \mathrm{mg} / \mathrm{ml})$ in distilled water was directly analysed by LC-MS. The compounds were separated on a reversed-phase Proshell 120 EC-C18 column $(4.6 \times 50 \mathrm{~mm}$; particle size $7 \mu \mathrm{m})$ (Agilent InfinityLab LC, Stevens Creek Blvd, Santa Clara, USA). The mobile phase consisted of two solvents: solvent A-water with $0.1 \%$ formic acid and solvent $\mathrm{B}$ - acetonitrile with $0.1 \%$ formic acid. A linear gradient was followed from $75 \%$ solvent A to $25 \%$ solvent A over $15 \mathrm{~min}$, ended by $2 \mathrm{~min}$ of column reequilibration at $75 \%$ solvent $\mathrm{A}$. The injection volume was $5 \mu \mathrm{l}$ and the flow rate $1 \mathrm{ml} / \mathrm{min}$.

TOF-MS parameters were as follows: ion spray voltage floating (ISVF) : $4500 \mathrm{~V}$; ion source gas 1 (GS 1): 45 psi; ion source gas 2 (GS 2): 45 psi; and temperature (TEM): $450^{\circ} \mathrm{C}$. Product ion parameters were as follows: the declustering potential (DP) was $60 \mathrm{~V}$, while collision energy (CE) was set at $35^{\circ} \mathrm{V}$. The spectra were recorded during ESI in negative mode at a mass range of m/z 50 and 1000. The acquisition was performed using Analyst Software and the data treatment, using XCMS online software (https://xcmsonline. scripps.edu) [35]. Hence, XCMS was used for preprocessing of all scanned data (3361 potential peaks) to extract potential molecular features, whose isotopic distribution was defined with peak spacing tolerance of $\mathrm{m} / \mathrm{z} 0.01$ and a mass accuracy of $10 \mathrm{ppm}$.

Ion formation during electrospray in negative mode using two ions $\left(\mathrm{H}^{-}\right.$and $\left.+\mathrm{Cl}^{-}\right)$was included to identify peaks with prospective metabolites. The resulting molecular ions were identified by examining the MS and MS/MS information in the Food Database (http://foodb.ca/) Version 1.0 (Canadian Institutes of Health Research (CIHR), Canada), with an error limit of $5 \mathrm{ppm}$. In addition, ChemSpider database software (Research Center, Raleigh, North Carolina, USA) was used to identify the molecular structure of each compound. Finally, the chemical structures of the compounds were drawn using ChemDraw 12.0 software, 
PerkinElmer (Perkin Elmer Ltd, Beaconsfield in Buckinghamshire, England).

\section{Results and Discussion}

3.1. Optimization of HIV-1 Protease Activity. Inhibition of HIV-1 protease activity is one of the primary aims in the development of antiviral agents for the treatment of HIVinfected patients [36]. The SensoLyte ${ }^{\circledR} 520$ HIV-1 protease assay kit (Cat no. AS-71147, AnaSpec, Fremont, California, USA) provides a convenient assay for high throughput screening of HIV-1 protease inhibitors and continuous quantification of HIV-1 protease activity using a FRET peptide as substrate. The general sequence of the FRET peptide is derived from the native p17/p24 cleavage site on protease gag for HIV-1 protease. Incubation of recombinant HIV-1 protease with the fluorogenic substrate results in specific cleavage at the Tyr-Pro bond and a time-dependent increase in fluorescence intensity that is linearly related to the extent of substrate hydrolysis, which can be monitored at excitation and emission wavelengths of $490 \mathrm{~nm}$ and $520 \mathrm{~nm}$, respectively. The fluorescence quantum yields of the HIV-1 protease substrate in the assay can increase up to 40.0- and 34.4-fold per mole of substrate cleaved.

To determine the optimal HIV-1 protease activity response concentration, the rate of substrate hydrolysis of 80 - and 800 fold diluted HIV-1 protease stock $(0.2 \mathrm{mg} / \mathrm{ml})$ was evaluated. The 80 -fold diluted stock yielded a time-dependant linear increase in fluorescence intensity, with a signal sufficient to measure inhibition, while the 800-fold dilution exhibited no fluorescence signal (Figure 1). The pepstatin A inhibitor effectively inhibited the 80 -fold diluted HIV-1 protease.

\subsection{Determination of the Inhibitory Effect of the Plant Extract} on HIV-1 Protease Activity. Medically, while the elusive cure to HIV/AID is still in progress, natural products from plants and their synthetic derivatives remain the alternative medicine for managing the disease. Some of these natural compounds that have demonstrated antiviral activities are found to inhibit vital enzymes and proteins critical to the life cycle of HIV, including the reverse transcriptase process, virus entry, integrase, and protease [37]. The extract of C. edulis used in the current study showed a remarkable anti-HIV enzyme activity against HIV-1 protease. The activity varied with respect to concentrations $(16-0.016 \mathrm{mg} / \mathrm{ml})$ against the 80 -fold diluted HIV-1 protease, which exhibited a high substrate hydrolysis rate, following a linear trend over 60 minutes (Figure 2). The inhibitor control completely $p<0.0001$ ) inhibited HIV-1 protease activity with $83.06 \%\left(\mathrm{IC}_{50} 1.6 \mathrm{mg} /\right.$ $\mathrm{ml})$. Treatment with all $C$. edulis extracts inhibited HIV-1 protease activity highly significant $(p<0.0001)$ at each time point during the linear curve $\left(R^{2}=0.9974\right)$ in a typical dose response manner. The most effective inhibition was observed with $16 \mathrm{mg} / \mathrm{ml}\left(75 \%, \mathrm{IC}_{50} 1.5 \mathrm{mg} / \mathrm{ml}\right)$ extract, which was significantly $(p<0.01)$ more effective than the other extract concentrations (Figures 2 and 3). The $1.6 \mathrm{mg} / \mathrm{ml}$ treatment was significantly more effective $\left(69 \%, \mathrm{IC}_{50} 1.4 \mathrm{mg} / \mathrm{ml}\right)$ than

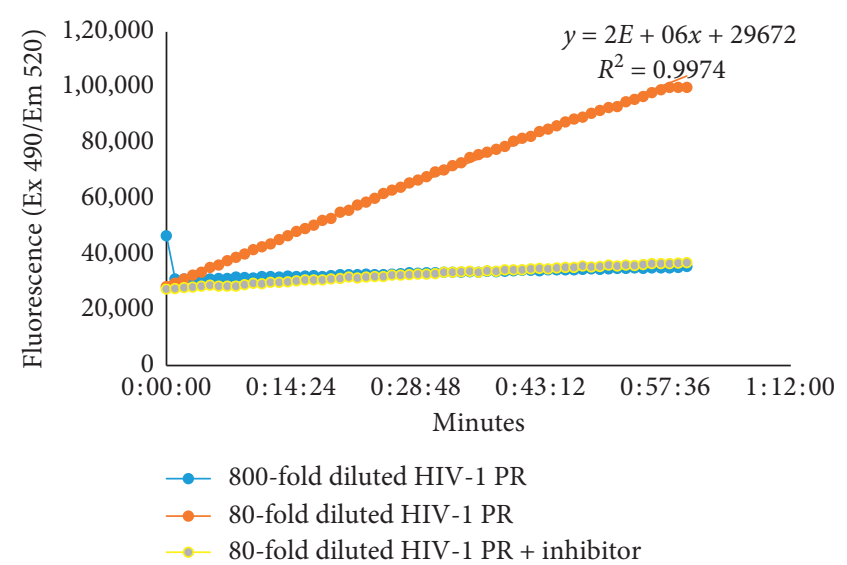

FIGURE 1: A kinetic linear progress graph presenting fluorescence intensity as a function of the rate of hydrolysis of the FRET peptide substrate over time in (i) 800 -fold diluted HIV-1 protease stock (blue), (ii) 80 -fold diluted HIV-1 protease stock $\left(R^{2}=0.9974\right)$ (orange), and (iii) 80-fold diluted HIV-1 stock and pepstatin A inhibitor (yellow).

the $0.16 \mathrm{mg} \cdot \mathrm{ml}(59.5 \%, 1.2 \mathrm{mg} / \mathrm{ml})$ treatment. There was no significant $(p>0.05)$ difference between the 0.016 and $0.16 \mathrm{mg} / \mathrm{ml}$ treatments. The plant extract treatments were slightly less effective $(p>0.05)$ than the inhibitor control.

Effective inhibition of HIV-1 protease activity by water extracts of several medicinal plant species has been reported worldwide. In South Africa, water extracts of Cassia garrettiana (94.6\% inhibition; $\mathrm{IC}_{50} 2.0$ ), Hypoxis sobolifera, and Bulbine alooides at $0.2 \mathrm{mg} / \mathrm{ml} \quad\left(>50 \%\right.$ inhibition; $\mathrm{IC}_{50}$ $1.19 \mathrm{mg} / \mathrm{ml}$ ) inhibited HIV-1 protease [38]. Water extracts of 18 medicinal plants from China, Japan, and Indonesia inhibited HIV-1 protease activity $>70 \%$ at concentrations between 25 and $250 \mu \mathrm{g} / \mathrm{ml}$ [39]. Among the extracts examined, Belamcanda chinensis, Magnolia fargesii, Paeonia suffruticosa, Phellodendron amurense, and Terminalia chebula were the most effective at $25 \mu \mathrm{g} / \mathrm{ml}$. The Ayurvedic Indian medicinal plants Areca catechu, Eugenia jambolana, Saraca indica, Adhatoda vasica, and Terminalia arjuna exhibited $>70 \%$ inhibition at $0.2 \mathrm{mg} / \mathrm{ml}\left(\mathrm{IC}_{50} 1.22-1.4 \mathrm{mg} /\right.$ $\mathrm{ml})[40,41]$. Water extracts of herbs indigenous to China, including Geum japonicum, Punica granatum, Rhus javanica, and Woodwardia orientilis exhibited $>70 \%$ inhibition at $250 \mu \mathrm{g} / \mathrm{ml}[42,43]$. Inhibition of HIV-1 protease activity by Fuscoporia obliqua harvested in Hokkaido, Japan, reduced enzyme activity by $50 \%$ at $2.5 \mu \mathrm{g} / \mathrm{ml}$ [44]. In Hong Kong, water extracts of Prunella vulgaris and Scutellaria baicalensis exhibited $90 \%$ inhibition at $200 \mathrm{mg} / \mathrm{ml}$ [45], while treatment with Paeonia suffruticosa and Mentha haplocalyx at $20 \mathrm{mg} / \mathrm{ml}$ resulted in $40 \%$ inhibition. Water extracts of the Thai medicinal plant species Dioscorea birmanica $(60 \mu \mathrm{g} / \mathrm{ml}$; $90 \%$ inhibition; $\left.\mathrm{IC}_{50} 4.5 \mu \mathrm{g} / \mathrm{ml}\right)$, Smilax corbularia $(70 \mu \mathrm{g} / \mathrm{ml}$; $>100 \%$; $\left.\mathrm{IC}_{50} 5.4 \mu \mathrm{g} / \mathrm{ml}\right)$, and Smilax glabra $(80 \%$; >100\%; IC $_{50} 8.5 \mu \mathrm{g} / \mathrm{ml}$ ) exhibited effective inhibition [46]. Rhus parviflora Roxb. is a popular medicinal herb that is widely distributed in Nepal, Northern India, Bhutan, and Sri Lanka which is used for the treatment of neurological disorders, including anxiety, insomnia, epilepsy, and rheumatoid 


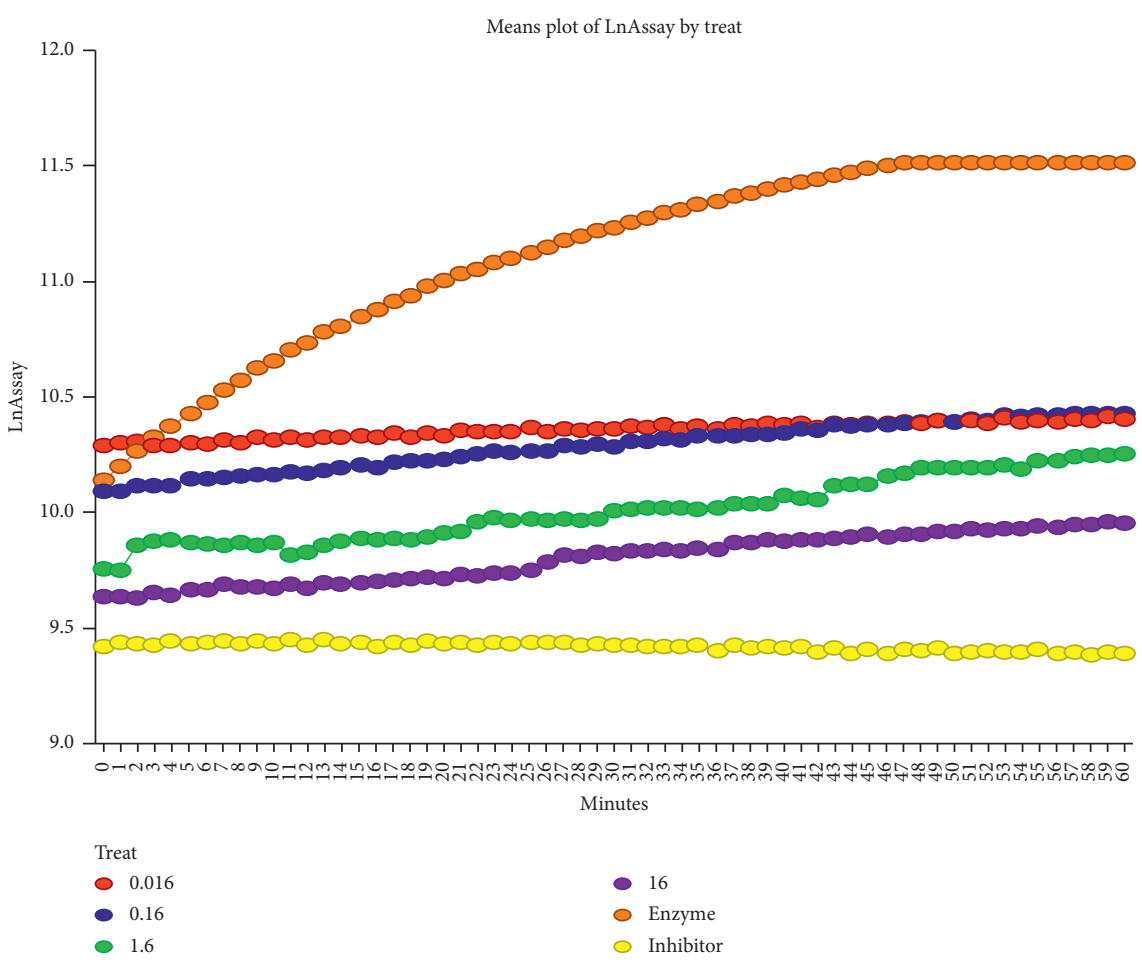

Figure 2: Treatment with all C. edulis extract concentrations inhibited HIV-1 protease activity at each time point during the linear curve $(p<0.0001)$. The observations show that most effective inhibition was $16 \mathrm{mg} / \mathrm{ml}\left(75 \%, \mathrm{IC}_{50} 1.5 \mathrm{mg} / \mathrm{ml}\right)(p<0.01)$.

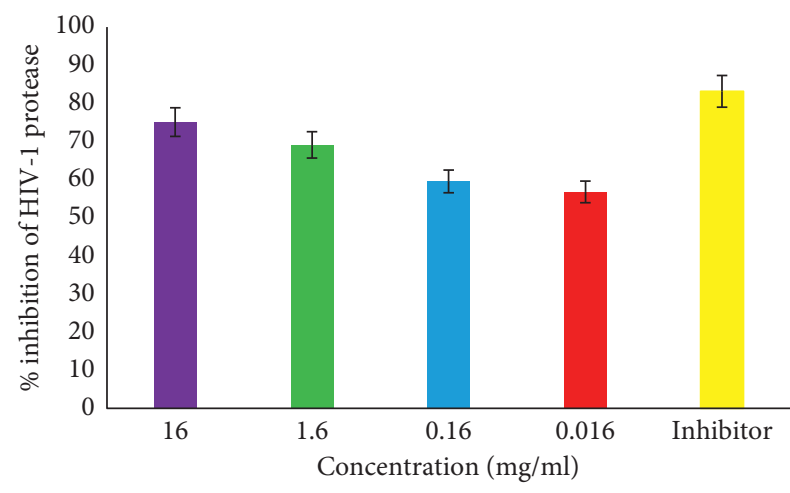

FIgURe 3: Percentage inhibition of HIV-1 protease activity by various concentrations. The inhibitor (pepstatin A) showed 83\% inhibitory effect on the enzyme. Each extract concentration significantly $(p<0.05)$ inhibited HIV-1 protease activity $>50 \%$.

arthritis [47]. A water extract of R. parviflora inhibited HIV1 protease activity in a dose-dependent manner (10, 20 and $50 \mu \mathrm{g} / \mathrm{ml}$ ) with maximum inhibition of $>65 \%$ at $50 \mu \mathrm{g} / \mathrm{ml}$ $\left(\mathrm{IC}_{50} 15 \mu \mathrm{g} / \mathrm{ml}\right)$ [47]. Acacia nilotica and Maytenus senegalensis, medicinal plant species of Sudan, significantly $(p<0.05)$ inhibited HIV-1 protease both at $100 \mathrm{mg} / \mathrm{ml}$ with $\mathrm{IC}_{50}$ values of $48 \mathrm{mg} / \mathrm{ml}$ and $88 \mathrm{mg} / \mathrm{ml}$, respectively. It should be noted that traditional healers do not prescribe organic solvent extracts of hexane or acetone to patients, rather they are conversant with natural solvents such as water or alcohol decoctions [28]. The toxicity of any medicinal plant should, however, be verified before administering to patients.
3.3. Cytotoxicity of C. edulis Water Extract. Scientific findings have shown that the majority of plant species used for medicinal purposes could be potentially toxic, mutagenic, and carcinogenic [48]. Researchers support the application of human cell lines for in vitro cytotoxicity assays to evaluate the toxicity of medicinal plants towards humans [49]. Carpobrotus edulis water extracts should be nontoxic or of low toxicity to human cells in order to be regarded as suitable for the development of preparations for the treatment of humans [49]. The negative controls containing untreated HeLa Chang cells exhibited high formazan formation rates during $72 \mathrm{~h}$ incubation in contrast with the positive controls, containing curcumin, which exhibited cytotoxicity towards the cells (Figure 4). There was no significant $(p>0.05)$ difference between the responses of the negative controls and $0.015,0.031,0.065,0.125,0.25,0.5$, and $1 \mathrm{mg} / \mathrm{ml}$ extract concentrations for all three time points, confirming no toxicity of $C$. edulis extracts towards HeLa Chang cells (Figure 4). Water extracts of medicinal plants with nonsignificant cytotoxicity include Sclerocarya birrea, a valued medicinal plant in South Africa, which possesses a variety of pharmacological attributes, including anti-inflammatory, antimicrobial, and antidiarrhea properties [50]. Due to its medicinal importance, water and acetone extracts were screened against various cancer cell lines, including HeLa Chang cells. Only the water extract was found nonsignificantly toxic to the cells [50]. A study by Sireeratawong et al. [51], revealed that water extract of Hibiscus sabdariffa showed weak toxicity in rats in vivo and was confirmed less harmful against HeLa Chang cell lines in vitro. Cytotoxicity evaluation of Brachylaena elliptica water extract also 


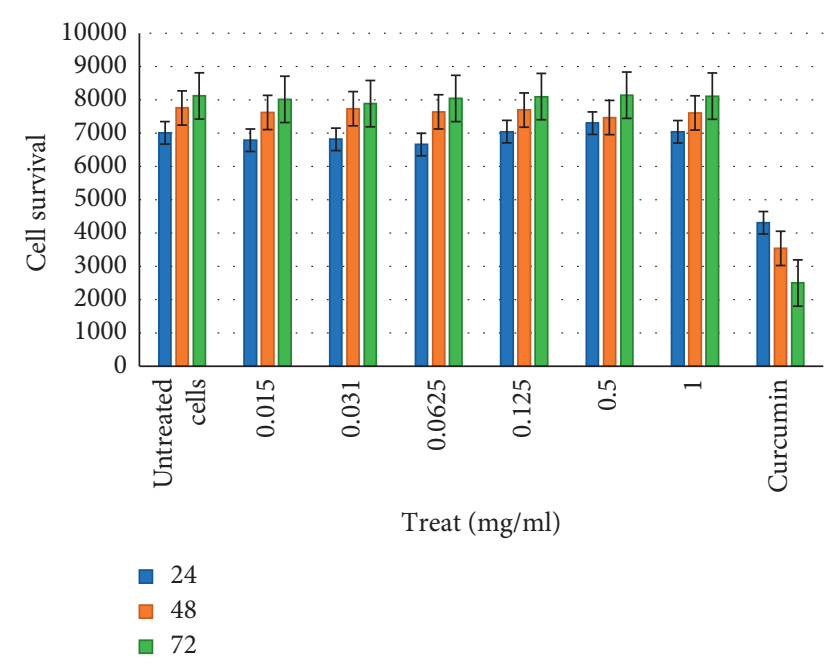

FIgURE 4: The cytotoxic effect of C. edulis water extract and curcumin (positive control) on HeLa Chang cells. Assays were performed in triplicate and results are expressed as the mean \pm standard deviation of three independent experiments. Viable cells treated with different concentrations of the extract did not affect cell survival at 24, 48, and $72 \mathrm{~h}$. Effect of curcumin monitored at same various hours was found toxic to the cells.

displayed low level of toxicity on HepG liver cells in all the doses tested [52].

3.4. Phytochemical Profile. Fourier-transform infrared (FTIR) spectrophotometer is regarded as the most accurate analytical technique for identifying chemical bonds and functional groups in plant compounds [53]. Chemical bonds together with their functional groups are determined from the highest to the lowest absorption band $\mathrm{cm}^{-1}$ peaks (Figure 5). The peak characteristic band at $3738 \mathrm{~cm}^{-1}$ shows the presence of $\mathrm{H}-\mathrm{O}$ stretching, indicating alcohols and phenols; at $2362 \mathrm{~cm}^{-1}$, none was detected; the characteristic band at $2090 \mathrm{~cm}^{-1}$ shows the $-\mathrm{C} \equiv \mathrm{C}$ - bending, indicating alkynes; the characteristic band at $1625 \mathrm{~cm}^{-1}$ shows $\mathrm{N}-\mathrm{H}$ stretching amines; the characteristic band at $1398 \mathrm{~cm}^{-1}$ shows $\mathrm{C}-\mathrm{O}-\mathrm{H}$ bending, indicating presence of alcohols; the characteristic band at $1131 \mathrm{~cm}^{-1}$ shows $\mathrm{C}-\mathrm{O}$ stretching carboxylic acids and esters; the characteristic band at $814 \mathrm{~cm}^{-1}$ shows out of plane, meaning none was detected; and the characteristic band at $620 \mathrm{~cm}^{-1}$ shows $\mathrm{C}-\mathrm{H}$ group, indicating the presence of alkanes (Table 1).

Phenols and alcohols, such as quercetin and flavonoids, are reported to have anti-inflammatory, antioxidant, and free radical scavenger properties [54]. In the past, phenol was the first antiseptic used in surgery. Anticancer activity of green tea cannabinoids is currently being used in cancer patients to palliate wasting, emesis, and pain that often accompany cancer [55]. The fruit aroma of pineapples, pears, and strawberries are caused by esters [56], which are applied as anesthetic [57]. Benzocaine, a carboxylic acid, is used to reduce dental pain [58]. Compounds containing benzene rings are used by the pharmaceutical industries to produce drugs, such as ibuprofen, aspirin, acetaminophen (tylenol), amphetamine, and sulphanilamide (NSAIDS). These drugs are used for toothache, back pain, menstrual cramps, muscle pain, pain from arthritis, fever, and the prevention of heart attacks or stroke (NSAIDS).

3.5. Identification of the Extracted Compounds by LC-ESITOF/MS. HIV-1 protease inhibitors (pls) are regulatory proteins found in numerous animal tissues and plants that reduce and inhibit proteases involved in human diseases like arthritis, pancreatitis, hepatitis, cancer, AIDS, thrombosis, emphysema, hypertension, and muscular dystrophy among others, thus pointing to possible applications in biomedicine, agriculture, and biotechnology [41]. The full scan acquisition of each compound peak was analysed using the peak view Analyst Software (ABSciex) [59]. The MS total ion chromatogram obtained from the analysis scanned in negative mode is shown in Figure 6. The negative mode was selected based on its sensitivity in detecting polyphenols, especially phenolic acids, flavonoids, and alkaloids. Chemical compounds present in the extract were identified using the XCMS software, followed by ChemSpider database software. Table 2 presents the class of compounds identified as $[\mathrm{M}-\mathrm{H}]^{-}$molecular ions and $\mathrm{m} / \mathrm{z}$ values. Structure assignment of the various molecular ions analysed is presented in Figure 7. Our discussion focuses on the identification of the most interesting compounds with anti-inflammatory activities.

In total, 8 phenolic acids were tentatively identified, including 2 flavonoids. Of these, 1 flavonoid and 1 phenolic acid were identified as the $[\mathrm{M}-\mathrm{P}]^{-}$. These were Di-ethoxydimethylphosphoramide $\left(\mathrm{C}_{6} \mathrm{H}_{18} \mathrm{~N}_{3} \mathrm{O}_{3} \mathrm{P}\right)$ at $\mathrm{m} / \mathrm{z} 211.108$ and 4-(Z)-hexadec-9-enoyl-amino-butyl dihydrogen phosphate $\left(\mathrm{C}_{20} \mathrm{H}_{40} \mathrm{NO}_{5} \mathrm{P}\right)$ at $\mathrm{m} / \mathrm{z} 211.108$. In addition, five ions were identified as $[\mathrm{M}-\mathrm{H}]^{-}$, including dimethyl-2-(2-nitrophenoxy)ethyl-azanium (m/z211.107); N,N $\mathrm{N}^{\prime}$-dicyclohexyl-4morpholinecarboxamidine ( $\mathrm{m} / \mathrm{z}$ 293.246); $\mathrm{N}$-(2-morpholin4-ylethyl)-4-(1,3-thiazol 2-ylmethyl)-1,4-diazepane-1-carbothioamide (m/z 369.165); 1-(4-amino-1,2,5-oxadiazol-3yl)-N-(4-dimethylaminophenyl)methylideneamino-5ethyltriazole-4 carboxamide (m/z 309.131); and 2-hydroxyethyl(tetradecan-2-yl) azanium-chloride (m/z 293.253). Only N-2-(2-chlorophenyl) sulfanyl-1-(1-cyclohexen-1-yl) ethyl-1-propanamine $\left(\mathrm{M}-\mathrm{C}_{17} \mathrm{H}_{24} \mathrm{NOCI}\right)$ was identified at retention time (RT) 6.5. Several polyphenolic derivatives, for example, resveratrol, tocopherols, phytosterols, and carotenoids, detected by the formation of $[\mathrm{M}-\mathrm{H}]^{-}$ions are known to possess antioxidants protecting the cells of the body from oxidative damage [31]. They provide a range of activities from inhibiting cancer cell proliferation to protecting the immune system against cardiovascular disease [31]. Evaluation of the anti-influenza activity of $1 \mathrm{H}-1,2,3$-triazole-4carboxamide derivatives at $[\mathrm{M}-\mathrm{H}]^{-}$was found to inhibit the replication of virus strains, including H5N1 (RG14), amantadine-resistant A/WSN/33 (H1N1), and oseltamivirresistant A/WSN/1933 (H1N1, 274Y) [60]. Antiproliferative activities of alpha-viniferin detected at $\mathrm{m} / \mathrm{z} 677.1817$ and hyperoside at $\mathrm{m} / \mathrm{z} 463.0882 \mathrm{M}-\mathrm{H}^{-}$were reported to reduce the growth of the human heptocellular carcinoma (HepG2) 


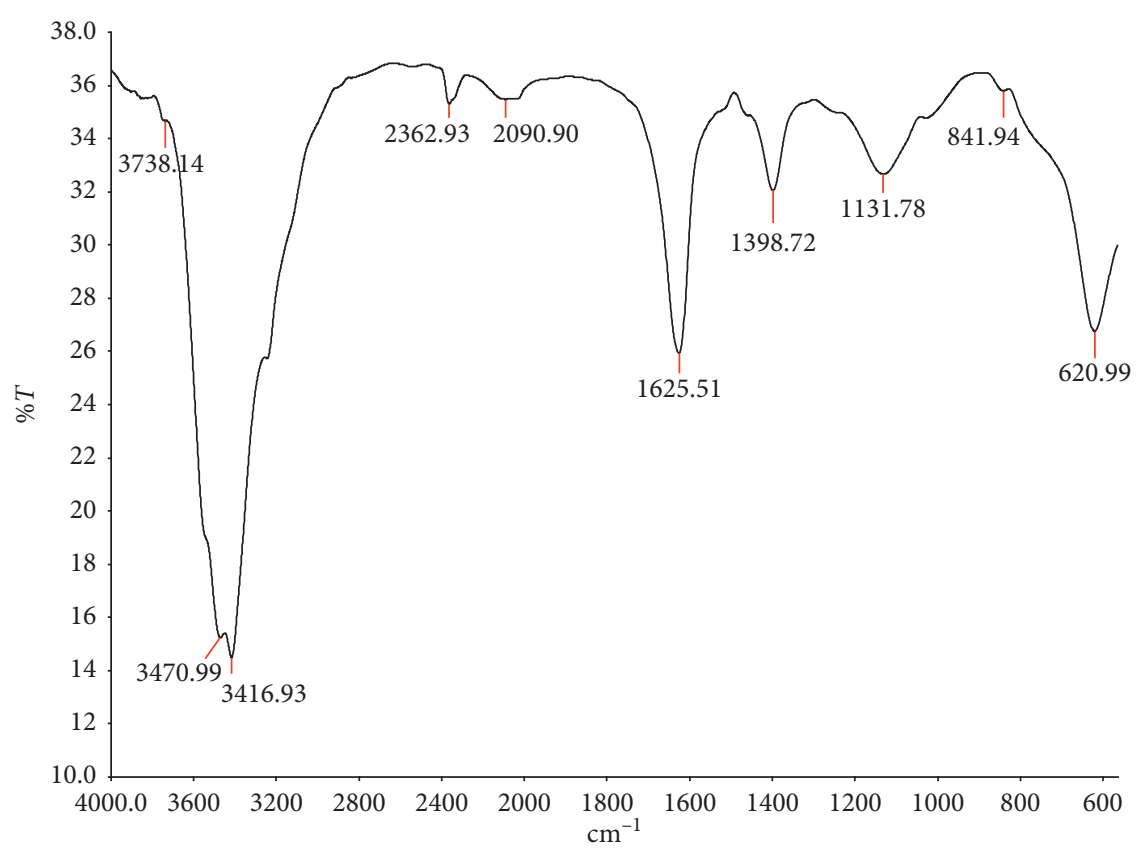

FIGURE 5: FT-IR spectrum of C. edulis water extract.

TABLE 1: Identified FT-IR peak values, functional groups, and compounds of C. edulis water extract.

\begin{tabular}{lcc}
\hline Identified peak values $\left(\mathrm{cm}^{-1}\right)$ & Functional groups & Nature of compounds \\
\hline $3738-3416$ & $\mathrm{O}-\mathrm{H}$ & Alcohols, phenols \\
2362 & $\mathrm{ND}$ & ND \\
2090 & $-\mathrm{C} \equiv \mathrm{C}-$ & Alkynes \\
1625 & $\mathrm{~N}-\mathrm{H}$ & Amines \\
1398 & $\mathrm{C}-\mathrm{O}-\mathrm{H}$ & Alcohols \\
1131 & $\mathrm{C}-\mathrm{O}$ & Carboxylic acids, esters \\
841 & $\mathrm{ND}$ & ND \\
620 & $\mathrm{C}-\mathrm{H}$ & Alkanes \\
\hline
\end{tabular}

ND: none detected.

cells and murine insulinoma (INS-1) cells [31]. Isoacteoside detected by the formation of the $[\mathrm{M}+\mathrm{CI}]^{-}$at $\mathrm{RT} 8.35$ was observed to have anticancer property [31].

Generally, phytochemicals are classified into six major categories based on their chemical structures and characteristics. These categories include carbohydrate, lipids, phenolics, terpenoids and alkaloids, and other nitrogencontaining compounds. Lipids serve five major functions in living organisms: they act as energy source, provide insulation and protection to organs, give structure to cell membranes, and generate heat when temperature changes [42]. Most people have enough lipids that act as a food source for 24 to 30 days [42]. About 4 important lipids were detected at the base peak of $[\mathrm{M}-\mathrm{H}]^{-}$at different retention times, including 3-acetyl-(2R)-6-methylhept-5-en-2-ylamino-propyl-dimethylazanium ( $\mathrm{m} / \mathrm{z} \quad 255.243)$, dibutox$\mathrm{y}$ (dihydroxy)phosphanium (m/z 405.262); 2-octyl-1-cyclopropene-1-octanoate (sterculate) (m/z 293.248), and vesnarinone $(\mathrm{m} / \mathrm{z}$ 405.54). Sterculates are vital natural compounds found in many plant species belonging to Sterculiaceae, Malvaceae, Tiliaceae, and Bombacaceae families [61]. They are majorly used as parasitic drugs to control insect and fungi infestation in plants [61]. Congestion of heart failure is a common problem associated with prognosis. Patients with an advanced stage of the disease are treated with vesnarinone [62]. The compound is a quinolinone derivative, a small molecule with phosphodiesterase 3 (PDE 3) inhibitor [63]. In vitro studies have shown that vesnarinone suppresses the production of TNF- $\alpha$ and IL- 6 in various human cell lines, including peripheral lymphocytes, monocytes, and T-cell lines [64]. It was also found to suppress cell proliferation and induces apoptosis on the expression of p21 in p53-mediated cell cycle [64]. Currently, a clinical trial of vesnarinone is being tested on patients with Kaposi sarcoma associated with HIV at the National Institute of Health (NIH).

Other compounds, belonging to alkaloids and nitrogencontaining compounds, were tentatively identified which reported antiproliferative activities. Two purine derivatives of 2$\mathrm{N}$-(4-aminocyclohexyl)-6-N-benzyl-9-cyclopentylpurine-2,6diamine $\left([\mathrm{M}-\mathrm{H}]^{-}\right.$at $\left.\mathrm{m} / \mathrm{z} 405.263\right)$ and 2-trans-(4-aminocy clohexyl) amino-6-(benzyl-amino)-9-cyclopentylpurine ([M$\mathrm{H}]^{-}$at $\mathrm{m} / \mathrm{z}$ 405.263) were identified at retention times of $12.5 \mathrm{~min}$ and $7.0 \mathrm{~min}$, respectively. The number of pyrimidine 


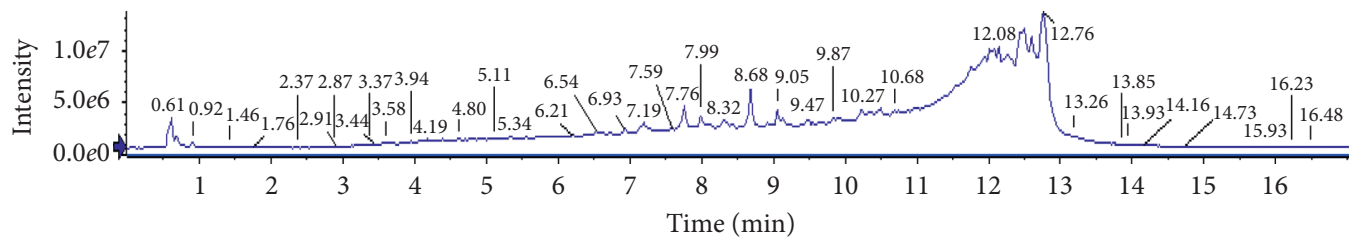

FIGURE 6: ESl-MS total ion chromatogram of the aqueous extract of C. edulis during negative ionization mode.

TABle 2: Putative identification of compounds in C. edulis showing the main parameters for their identification.

\begin{tabular}{|c|c|c|c|c|c|c|c|}
\hline $\begin{array}{l}\text { Class of } \\
\text { compounds }\end{array}$ & Putative identification & Mass & $\mathrm{m} / \mathrm{z}$ & Adduct & $\begin{array}{c}\mathrm{RT} \\
(\mathrm{min})\end{array}$ & $\begin{array}{c}\delta \\
(\mathrm{ppm})\end{array}$ & Formula \\
\hline \multirow{2}{*}{ Flavonoids } & Di-ethoxydimethylphosphoramide & 211.202 & 211.108 & {$[\mathrm{M}-\mathrm{P}]^{-}$} & 0.5 & 3.2 & $\mathrm{C}_{6} \mathrm{H}_{18} \mathrm{~N}_{3} \mathrm{O}_{3} \mathrm{P}$ \\
\hline & Dimethyl-2-(2-nitrophenoxy)ethyl-azanium & 211.241 & 211.107 & {$[\mathrm{M}-\mathrm{H}]^{-}$} & 0.5 & 3.2 & $\mathrm{C}_{10} \mathrm{H}_{15} \mathrm{~N}_{2} \mathrm{O}_{3}$ \\
\hline \multirow{6}{*}{ Phenolic acids } & N,N'-Dicyclohexyl-4-morpholinecarboxamidine & 293.455 & 293.246 & {$[\mathrm{M}-\mathrm{H}]^{-}$} & 14.0 & 1.7 & $\mathrm{C}_{17} \mathrm{H}_{31} \mathrm{~N}_{3} \mathrm{O}$ \\
\hline & $\begin{array}{c}\text { N-(2-Morpholin-4-ylethyl)-4-(1,3-thiazol 2-ylmethyl)- } \\
\text { 1,4-diazepane-1-carbothioamide }\end{array}$ & 369.546 & 369.165 & {$[\mathrm{M}-\mathrm{H}]^{-}$} & 4.5 & 3.2 & $\mathrm{C}_{16} \mathrm{H}_{10} \mathrm{~N}_{9} \mathrm{O}_{2}$ \\
\hline & $\begin{array}{l}\text { 1-(4-Amino-1,2,5-oxadiazol-3-yl)-N-(4- } \\
\text { dimethylaminophenyl)methylideneamino-5- } \\
\text { ethyltriazole-4-carboxamide }\end{array}$ & 369.389 & 309.131 & {$[\mathrm{M}-\mathrm{H}]^{-}$} & 1.5 & 5.0 & $\mathrm{C}_{16} \mathrm{H}_{19} \mathrm{~N}_{9} \mathrm{O}_{2}$ \\
\hline & $\begin{array}{c}\text { N-2-(2-Chlorophenyl)sulfanyl-1-(1-cyclohexen-1-yl) } \\
\text { ethyl-1-propanamine }\end{array}$ & 309.896 & 361.176 & {$[\mathrm{M}+\mathrm{Cl}]^{-}$} & 6.5 & 0.2 & $\mathrm{C}_{17} \mathrm{H}_{24} \mathrm{NOCl}$ \\
\hline & 2-Hydroxyethyl(tetradecan-2-yl) azanium-chloride & 293.92 & 293.253 & {$[\mathrm{M}-\mathrm{H}]^{-}$} & -0.5 & -2.5 & $\mathrm{C}_{19} \mathrm{H}_{33} \mathrm{O}_{2}$ \\
\hline & $\begin{array}{l}\text { 4-(Z)-Hexadec-9-enoyl-amino-butyl dihydrogen } \\
\text { phosphate }\end{array}$ & 405.516 & 361.177 & {$[\mathrm{M}-\mathrm{P}]^{-}$} & 2.5 & -2.1 & $\mathrm{C}_{20} \mathrm{H}_{40} \mathrm{NO}_{5} \mathrm{P}$ \\
\hline \multirow{4}{*}{$\begin{array}{l}\text { Lipid } \\
\text { derivatives }\end{array}$} & $\begin{array}{c}\text { 3-Acetyl-(2R)-6-methylhept-5-en-2-yl-amino-propyl- } \\
\text { dimethylazanium }\end{array}$ & 255.426 & 255.243 & {$[\mathrm{M}-\mathrm{H}]^{-}$} & 5.0 & 4.6 & $\mathrm{C}_{15} \mathrm{H}_{31} \mathrm{NO}_{2}$ \\
\hline & Dibutoxy(dihydroxy)phosphanium & 211.218 & 405.262 & {$[\mathrm{M}-\mathrm{P}]^{-}$} & 0.5 & 2.2 & $\mathrm{C}_{8} \mathrm{H}_{20} \mathrm{O}_{4} \mathrm{P}$ \\
\hline & 2-Octyl-1-cyclopropene-1-octanoate (Sterculate) & 293.471 & 293.248 & {$[\mathrm{M}-\mathrm{H}]^{-}$} & 4.0 & -1.4 & $\mathrm{C}_{19} \mathrm{H}_{33} \mathrm{O}_{2}$ \\
\hline & Vesnarinone & 405.53 & 405.54 & {$[\mathrm{M}-\mathrm{H}]^{-}$} & 1.5 & 5.0 & $\mathrm{C}_{22} \mathrm{H}_{35} \mathrm{~N}_{3} \mathrm{O}_{4}$ \\
\hline \multirow{2}{*}{$\begin{array}{l}\text { Purine } \\
\text { derivatives }\end{array}$} & $\begin{array}{l}\text { 2-N-(4-Aminocyclohexyl)-6-N-benzyl-9- } \\
\text { cyclopentylpurine-2,6-diamine }\end{array}$ & 405.55 & 405.263 & {$[\mathrm{M}-\mathrm{H}]^{-}$} & 12.5 & -1.3 & $\mathrm{C}_{23} \mathrm{H}_{31} \mathrm{~N}_{7}$ \\
\hline & $\begin{array}{l}\text { 2-trans-(4-Aminocyclohexyl) amino-6-(benzyl- } \\
\text { amino)-9-cyclopentylpurine }\end{array}$ & 405.55 & 405.263 & {$[\mathrm{M}-\mathrm{H}]^{-}$} & 7.0 & -1.4 & $\mathrm{C}_{24} \mathrm{H}_{37} \mathrm{O}_{5}$ \\
\hline \multirow{3}{*}{$\begin{array}{l}\text { Pyrimidine } \\
\text { derivatives }\end{array}$} & $\begin{array}{l}\text { Amino-(4-benzamidoanilino) methylidene-(4,6 } \\
\text { dimethylpyrimidin-2-yl) azanium }\end{array}$ & 361.429 & 361.177 & {$[\mathrm{M}-\mathrm{H}]^{-}$} & 7.5 & 2.0 & $\mathrm{C}_{20} \mathrm{H}_{21} \mathrm{~N}_{6} \mathrm{O}$ \\
\hline & $\begin{array}{l}\text { (2S)-4-(1-Methylpyrrole-2-carbonyl)-N-(3S)-2- } \\
\text { oxopiperidin-3-yl]-1-(piperidin-1-ium-4-carbonyl) } \\
\text { piperazine-2-carboxamide }\end{array}$ & 445.544 & 445.255 & {$[\mathrm{M}-\mathrm{H}]^{-}$} & 2.0 & -0.4 & $\mathrm{C}_{22} \mathrm{H}_{33} \mathrm{~N}_{6} \mathrm{O}_{4}$ \\
\hline & $\begin{array}{l}\mathrm{N} \text {-(3-Chloro-4-methylphenyl)-6-(4-ethyl-1- } \\
\text { piperazinyl) methyl-1,3,5-triazine-2,4-diamine }\end{array}$ & 361.878 & 293.247 & {$[\mathrm{M}+\mathrm{Cl}]^{-}$} & 9.5 & 0.4 & $\mathrm{C}_{17} \mathrm{H}_{24} \mathrm{~N}_{7} \mathrm{Cl}$ \\
\hline Vitamin B & $\begin{array}{l}\text { 2-4-Amino-6-(3S)-3-methylpiperidin-1-yl-5- } \\
\text { nitropyrimidin-2-yl-amino-acetate }\end{array}$ & 309.306 & 309.130 & {$[\mathrm{M}-\mathrm{H}]^{-}$} & 8.0 & 2.3 & $\mathrm{C}_{2} \mathrm{H}_{17} \mathrm{~N}_{6} \mathrm{O}_{4}$ \\
\hline $\begin{array}{l}\text { Quinolinone } \\
\text { derivative }\end{array}$ & $\begin{array}{l}\text { 1R,9aR-1,2,3,4,5,6,7,8,9,9a-Decahydroquinolizin-5- } \\
\text { ium-1-yl-methoxy-methyl-pentoxy-sulfanylidene- } \\
\text { lambda-5-phosphane-chloride }\end{array}$ & 405.539 & 405.262 & {$[\mathrm{M}+\mathrm{CI}]^{-}$} & 10.0 & 0.9 & $\mathrm{C}_{16} \mathrm{H}_{33} \mathrm{NO}_{2} \mathrm{PSCl}$ \\
\hline
\end{tabular}

derivatives identified at base peaks of $[\mathrm{M}-\mathrm{H}]^{-}$was two and one chlorine-ion $[\mathrm{M}+\mathrm{Cl}]^{-}$, including amino-(4-benzamidoanilino) methylidene-(4,6 dimethylpyrimidin-2-yl) azanium $(\mathrm{m} / \mathrm{z}$ 361.177); (2S)-4-(1-methylpyrrole-2-carbonyl)-N-(3S)-2-oxopiperidin-3-yl]-1-(piperidin-1-ium-4-carbonyl) piperazine-2carboxamide (m/z 445.255); and N-(3-chloro-4-methylphenyl)-6-(4-ethyl-1-piperazinyl) methyl-1,3,5-triazine-2,4diamine $\left(\mathrm{m} / \mathrm{z} 293.247-\mathrm{C}_{17} \mathrm{H}_{24} \mathrm{~N}_{7} \mathrm{CI}\right)$. A pronounced vitamin B- $\mathrm{C}_{2} \mathrm{H}_{17} \mathrm{~N}_{6} \mathrm{O}_{4}$ was observed at m/z 309.130 (RT 8.0 min) and a quinolinone derivative of $1 \mathrm{R}, 9 \mathrm{aR}-1,2,3,4,5,6,7,8,9,9 \mathrm{a}$-decahydroquinolizin-5-ium-1-yl-methoxy-methyl-pentoxy- sulfanylidene-lambda-5-phosphane-chloride $\left[\mathrm{M}-\mathrm{C}_{16} \mathrm{H}_{33} \mathrm{NO}_{2}\right.$ PSCI] was observed at $10.0 \mathrm{~min}$ retention time. Purines and pyrimidine derivatives are essential building blocks of nucleic acids, DNA, and RNA. They are used to produce drugs that treat multiple cancers, respiratory inflammations, and HIV/ AIDS [65]. The drugs are also recommended for preterm labor, premature birth, and for controlling labor prior to caesarean delivery [66]. B vitamins are especially important for women who are pregnant and breastfeeding. The vitamins boost energy levels, ease nausea, aid in fetal brain development, and reduce the risk of birth defects. A deficiency of 
<smiles>CN(C)P(=O)(N(C)CO)N(C)CO</smiles>

(a)<smiles>C1CCC(N=C(NC2CCCCC2)N2CCOCC2)CC1</smiles>

(c)<smiles>CC/C(C)=N\NC(=O)C1=C(CNc2ccccc2)C(c2nonc2N)N=N1</smiles>

(e)<smiles>C[N+](C)(C)Cc1c(O)cccc1[N+](=O)[O-]</smiles>

(b)<smiles>S=C(NCCN1CCOCC1)N1CCCN(Cc2nccs2)CC1</smiles>

(d)<smiles>CCCNC(CSc1ccccc1Cl)C1=CCCCC1</smiles>

(f)<smiles>CCCCCCCCCCN(CCC)CCCO</smiles>

(g)<smiles>C=C(C)C(=O)NCCCCCCCC[N+](C)(C)C</smiles>

(i)<smiles>CNCCCN(C(C)=O)[C@@H](C)CCC=C(C)C</smiles>

(k)<smiles>Cn1ncc2c(NC3CCCCC3)nc(N3CCN(Cc4ccccc4)CC3)nc21</smiles>

$(\mathrm{m})$<smiles>CCCCO[PH+](O)OCCCC</smiles>

(j)<smiles>COc1ccc(C(=O)N2CCN(c3ccc4c(c3)CCC(=O)N4)CC2)cc1OC</smiles>

(l)

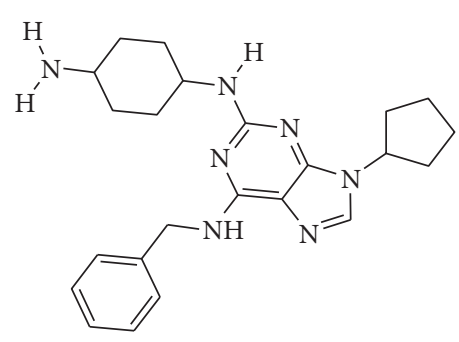

(n)

Figure 7: Continued. 
<smiles>CCc1ccc(NC2=N[C@@H](c3cccnc3)[n+]3c([nH]c(C)cc3=O)N2)cc1</smiles>

(o)<smiles></smiles>

(q)<smiles>Cn1cccc1C(=O)N1CCN(C(=O)C2CC[NH2+]CC2)[C@H](C(=O)N[C@H]2CCCNC2=O)C1</smiles>

$(\mathrm{p})$<smiles>C[C@H]1CCCN(c2nc(NCC(=O)[O-])nc(N)c2[N+](=O)[O-])C1</smiles>

$(\mathrm{r})$<smiles>CCCCCOP(C)(=S)OC[C@H]1CCC[NH+]2CCCC[C@H]12</smiles>

(s)

Figure 7: Chemical structures of main identified compounds. (a) Di-ethoxydimethylphosphoramide. (b) Dimethyl-2-(2-nitrophenoxy)ethylazanium. (c) N,N'-Dicyclohexyl-4-morpholinecarboxamidine. (d) N-(2-Morpholin-4-ylethyl)-4-(1,3-thiazol 2-ylmethyl)-1,4-diazepane-1-carbothioamide. (e) 1-(4-Amino-1,2,5-oxadiazol-3-yl)-N-(4-dimethylaminophenyl)methylideneamino-5-ethyltriazole-4-carboxamide. (f) N-2-(2Chlorophenyl)sulfanyl-1-(1-cyclohexen-1-yl)ethyl-1-propanamine. (g) 2-Hydroxyethyl(tetradecan-2-yl) azanium chloride. (h) 4-(Z)-Hexadec-9enoyl-amino-butyl dihydrogen phosphate. (i) 3-Acetyl-(2R)-6-methylhept-5-en-2-yl-amino-propyl-dimethylazanium. (j) Dibutoxy(dihydroxy) phosphanium. (k) 2-Octyl-1-cyclopropene-1-octanoate (sterculate). (l) Vesnarinone. (m) 2-N-(4-Aminocyclohexyl)-6-N-benzyl-9-cyclopentylpurine-2,6-diamine. (n) 2-trans-(4-Aminocyclohexyl) amino-6-(benzyl-amino)-9-cyclopentylpurine. (o) Amino-(4-benzamidoanilino) methylidene-(4,6 dimethylpyrimidin-2-yl) azanium. (p) (2S)-4-(1-Methylpyrrole-2-carbonyl)-N-(3S)-2-oxopiperidin-3-yl]-1-(piperidin-1-ium-4carbonyl) piperazine-2-carboxamide. (q) N-(3-Chloro-4-methylphenyl)-6-(4-ethyl-1-piperazinyl) methyl-1,3,5-triazine-2,4-diamine. (r) Vitamin B. (s) 1R,9aR-1,2,3,4,5,6,7,8,9,9a-Decahydroquinolizin-5-ium-1-yl-methoxy-methyl-pentoxy-sulfanylidene-lambda-5-phosphane-chloride.

vitamin B1 (thiamine) may cause severe neurological symptoms.

\section{Conclusions}

The current study showed the in vitro anti-HIV enzyme activity of $C$. edulis aqueous leave extract. Water extract of $C$. edulis highly significantly $(P<0.0001)$ inhibits HIV-1 protease activity with no cytotoxic effect on HeLa Chang cells. Profiling of compounds present in the extract by LC-TOFMS tentatively revealed a total of 19 compounds, mainly on the basis of accurate mass measurements of the metabolites. Purines and pyrimidine derivatives are compounds with reported anti-HIV activities. However, a second phase of study involving more detailed biological activities of each compound inhibition on the enzyme must be performed. Our current work and study will lead to follow a more specific route to better understand the activity of extract fraction.

\section{Data Availability}

All data generated or analysed during this study are included within the article.

\section{Conflicts of Interest}

The authors declare that there are no conflicts of interest regarding the publication of this paper. 


\section{Acknowledgments}

This research was supported by grants from National Research Foundation and Govan Mbeki Research and Development Centre, University of Fort Hare. The authors also thank the Applied Microbial and Health Biotechnology Institute, Cape Peninsula University of Technology, for the support.

\section{References}

[1] W. Zhang, S. Cao, J. L. Martin, J. D. Mueller, and L. M. Mansky, "Morphology and ultrastructure of retrovirus particles," AIMS Biophysics, vol. 2, no. 3, pp. 343-369, 2015.

[2] G. Hu, A. Ma, X. Dou, L. Zhao, and J. Wang, "Computational studies of a mechanism for binding and drug resistance in the wild type and four mutations of HIV-1 protease with a GRL0519 inhibitor," International Journal of Molecular Sciences, vol. 17, no. 6, p. 819, 2016.

[3] F. Pietrucci, A. V. Vargiu, and A. Kranjc, "HIV-1 protease dimerization dynamics reveals a transient druggable binding pocket at the interface," Scientific Reports, vol. 518555 pages, 2015.

[4] M. Perrier, L. Castain, L. Regad et al., "HIV-1 protease, Gag and gp41 baseline substitutions associated with virological response to a PI-based regimen," Journal of Antimicrobial Chemotherapy, vol. 74, no. 6, pp. 1679-1692, 2019.

[5] B. Trinite, H. Zhang, and D. N. Levy, "NNRTI-induced HIV-1 protease-mediated cytotoxicity induces rapid death of CD4 T cells during productive infection and latency reversal," Retrovirology, vol. 16, no. 17, 2019.

[6] B. B. Finlay and G. McFadden, "Anti-immunology: evasion of the host immune system by bacterial and viral pathogens," Cell, vol. 124, no. 4, pp. 767-782, 2006.

[7] L. Huang, L. Li, C. F. Tien, D. V. LaBarbera, and C. Chen, "Targeting HIV-1 protease autoprocessing for highthroughput drug discovering and drug resistance assessment," Scientific Reports, vol. 9, no. 301, 2019.

[8] C. G. Whiteley, C.-Y. Shing, C.-C. Kuo, and D.-J. Lee, "Docking of HIV protease to silver nanoparticles," Journal of the Taiwan Institute of Chemical Engineers, vol. 60, pp. 83-91, 2016.

[9] Q. Wang, X. Zhang, Y. Han, X. Wang, and G. Gao, "M2BP inhibits HIV-1 virion production in a vimentin filamentsdependent manner," Scientific Report, vol. 632736 pages, 2016.

[10] W. I. Sundquist and H.-G. Krausslich, "HIV-1 assembly, budding, and maturation," Cold Spring Harbor Perspectives in Medicine, vol. 2, no. 7, Article ID a006924, 2012.

[11] M. R. Dayer and M. S. Dayer, "Whiskers-less HIV-protease: a possible way for HIV-1 deactivation," Journal of Biomedical Science, vol. 20, no. 67, 2013.

[12] L. Charlotte, "What type of HIV medications are there? medical new today," MediLexicon International, vol. 28, 2019.

[13] M. Zhu, B. Dong, G.-N. Zhang, J.-X. Wang, S. Cen, and Y.-C. Wang, "Synthesis and biological evaluation of new HIV1 protease inhibitors with purine bases as P2-ligands," Bioorganic \& Medicinal Chemistry Letters, vol. 29, no. 12, pp. 1541-1545, 2019.

[14] J. Konvalinda, H. Krausslich, and B. Muller, "Retroviral proteases and their roles in virion maturation," Virology, vol. 479-480, pp. 403-417, 2015.

[15] A. M. J. Wensing, A. Fun, and M. Nijhuis, "HIV pprotease iinhibitor rresistance," Handbook Oof Antimicrobial Resistance, Springer, Berlin, Germany, pp. 1-31, 2014.
[16] A. K. Ghosh, J. N. Williams, R. Y. Ho, H. M. Simpson, S.-i. Hattori, H. Hayashi et al., "Design and synthesis of potent HIV-1 protease inhibitors containing bicyclic oxazolidinone scaffold as the P2 ligands: structure-activity studies and biological and X-ray structural studies," Journal of Medicinal Chemistry, vol. 61, no. 21, pp. 9722-9737, 2018.

[17] C. J. Bungard, P. D. Williams, J. Schulz et al., "Design and synthesis of piperazine sulfonamide cores leading to highly potent HIV-1 protease inhibitors," ACS Medicinal Chemistry Letters, vol. 8, no. 12, pp. 1292-1297, 2017.

[18] C. Su, W. Ling, W. Lua, Y. Haw, and S. Gan, "Structural analyses of 2015-updated drug-resistant mutations in HIV-1 protease: an implication of protease inhibitor cross-resistance," BMC Bioinformatics, vol. 17, no. 19, p. 500, 2016.

[19] R. Lene, L. J. Dilling, D. W. Stephane et al., "Use of antiretroviral therapy and risk of end-stage liver disease and hepatocellular carcinoma in HIV-positive persons," AIDS, vol. 30, no. 11, pp. 1731-1743, 2016.

[20] I. D. Ramsay, J. M. Lestner, C. P. O’Sullivan, A. L. G. Cruz, H. K. Li, and C. I. S. Barker, "Antiviral drugs," Side Effects of Drugs Annual, Elsevier, vol. 36, pp. 401-443, Amsterdam, Netherlands, 2014.

[21] G. I. Gasim, A. Bella, and I. Adam, "Schistosmiasis, hepatitis B and hepatitis C co-infection," Virology, vol. 8, no. 12, p. 19, 2015.

[22] A. A. Adom and R. Ofori-Asenso, "Prevalence of HIV and hepatitis B coinfection in Ghana: a systematic review and meta-analysis," AIDS Research and Therapy, vol. 13, no. 23, 2016.

[23] C. E. Reust, "Common adverse effects of antiretroviral therapy for HIV disease," American Family Physician, vol. 83, no. 12, pp. 1443-51, 2011.

[24] K. Fern, Plant for a Future: Edible and Useful Plants for a Healthier World, p. 165, Permanent Publications, East Meon, UK, 2013.

[25] P. Chesselet, G. F. Smith, P. M. Burgoyne et al., "Seed plants of South Africa," Strelitzia, vol. 10, pp. 360-410, 2000.

[26] B. E. Omoruyi, G. Bradley, and A. J. Afolayan, "Antioxidant and phytochemical properties of Carpobrotus edulis (L.) bolus leaf used for the management of common infections in HIV/ AIDS patients in Eastern Cape Province,", BMC Complementary and Alternative Medicine, vol. 12, no. 1, p. 215, 2012.

[27] L. V. Buwa and A. J. Afolayan, "Antimicrobial activity of some medicinal plants used for the treatment of tuberculosis in the Eastern Cape Province, South Africa," African Journal of Biotechnology, vol. 8, no. 23, pp. 6683-6687, 2009.

[28] B. E. Omoruyi, G. Bradley, and A. J. Afolayan, "Ethnomedicinal survey of medicinal plants used for the management of HIV/AIDS infection among local communities of Nkonkobe Municipality Eastern Cape South Africa," Journal of Medicinal Plant Research, vol. 6, no. 19, pp. 3603-3608, 2012.

[29] B. Omoruyi, A. Afolayan, and G. Bradley, "Chemical composition profiling and antifungal activity of the essential oil and plant extracts of Mesembryanthemum edule (L.) Bolus leaves," African Journal of Traditional, Complementary and Alternative Medicines, vol. 11, no. 4, pp. 19-30, 2014.

[30] W. Otang, D. Grierson, and R. Ndip, "Cytotoxicity of three South African medicinal plants using the Chang liver cell line," African Journal of Traditional, Complementary and Alternative Medicines, vol. 11, no. 2, pp. 324-329, 2014.

[31] A. Akinrinde, M. V. d. Venter, T. Koekemoer, and G. Bradley, "Anti-proliferative activities of the aqueous root extract of Dianthus thunbergii ss hooper (Caryophyllaceae)," African 
Journal of Traditional, Complementary and Alternative Medicines, vol. 15, no. 4, pp. 32-44, 2018.

[32] E. Chan-Penebre, K. G. Kuplast, C. R. Majer et al., "A selective inhibitor of PRMT5 with in vivo and in vitro potency in MCL models," Nature Chemical Biology, vol. 11, no. 6, pp. 432-437, 2015.

[33] NCSS 2019 Statistical Software, "NCSS, LLC. Kaysville, Utah, USA," ncss.com/software/ncss, 2019.

[34] M. Visveshwar, B. Subbaiyan, and V. Thangapandian, "Phytochemical analysis, antibacterial activity, FTIR AND GCMS analysis of Ceropegia Juncea Roxb," International of Journal of Pharmacognosy and Phytochemical Research, vol. 9, no. 7, pp. 914-920, 2018.

[35] C. A. Smith, E. J. Want, G. O'Maille, R. Abagyan, and G. Siuzdak, "XCMS: processing mass spectrometry data for metabolite profiling using nonlinear peak alignment, matching, and identification," Analytical Chemistry, vol. 78, no. 3, pp. 779-787, 2006.

[36] J. Meng, M.-T. Lai, V. Munshi et al., "Screening of HIV-1 protease using a combination of an ultra-high-throughput fluorescent-based assay and RapidFire mass spectrometry," Journal of Biomolecular Screening, vol. 20, no. 5, pp. 606-615, 2015.

[37] S. Tewtrakul, S. Subhadhirasakul, and S. Kummee, "HIV-1 protease inhibitory effects of medicinal plants used as selfmedication by AIDS patients," Songklanakarin Journal of Science and Technology, vol. 25, no. 2, pp. 239-243, 2003.

[38] M. Klos, M. van de Venter, P. J. Milne, H. N. Traore, D. Meyer, and V. Oosthuizen, "In vitro anti-HIV activity of five selected South African medicinal plant extracts," Journal of Ethnopharmacology, vol. 124, no. 2, pp. 182-188, 2009.

[39] J. C. Alves-Filho, F. Sônego, F. O. Souto et al., "Interleukin-33 attenuates sepsis by enhancing neutrophil influx to the site of infection," Nature Medicine, vol. 16, no. 6, pp. 708-712, 2010.

[40] B. Singh, V. Gupta, P. Bansal, R. Singh, and D. Kumer, "Pharmacological potential of plant used as aphrodisiacs," International Journal of Pharmaceutical Sciences Review and Research, vol. 5, no. 1, pp. 104-107, 2010.

[41] M. M. Nutan, B. Pancholi, S. Kulshrestha et al., "Anti-HIV-1 activity, protease inhibition and safety profile of extracts prepared from Rhus parviflora," BMC Complementary and Alternative Medicine, vol. 13, p. 152, 2013.

[42] G. Hussein, H. Miyashiro, N. Nakamura et al., "Inhibitory effects of Sudanese plant extracts on HIV-1 replication and HIV-1 protease," Phytotherapy Research, vol. 13, no. 1, pp. 31-36, 1999.

[43] T. Ichimura, O. Watanabe, and S. Maruyama, "Inhibition of HIV-1 protease by water-soluble lignin-like substance from an edible mushroom, Fuscoporia obliqua," Bioscience, Biotechnology, and Biochemistry, vol. 62, no. 3, pp. 575-577, 1998.

[44] T. L. Lam, M. L. Lam, T. K. Au et al., "A comparison of human immunodeficiency virus type-1 protease inhibition activities by the aqueous and methanol extracts of Chinese medicinal herbs," Life Sciences, vol. 67, no. 23, pp. 2889-2896, 2000.

[45] S. Tewtrakul, A. Itharat, and P. Rattanasuwan, "Anti-HIV-1 protease and HIV-1 integrase activities of Thai medicinal plants known as Hua-Khao-Yen," Journal of Ethnopharmacology, vol. 105, no. 1-2, pp. 312-315, 2006.

[46] S. Shrestha, J.-H. Park, D.-Y. Lee et al., "Rhus parviflora and its biflavonoid constituent, rhusflavone, induce sleep through the positive allosteric modulation of GABAA-benzodiazepine receptors," Journal of Ethnopharmacology, vol. 142, no. 1, pp. 213-220, 2012.
[47] B. L. Tan and M. S. Norhaizan, "Scientific evidence of rice byproducts for cancer prevention: chemopreventive properties of waste products from rice milling on carcinogenesis in vitro and in vivo," BioMed Research International, vol. 2017, Article ID 9017902, 18 pages, 2017.

[48] P. Kapewangolo, M. Kandawa-Schulz, and D. Meyer, "AntiHIV activity of Ocimum labiatum extract and isolated Pheophytin-a," Molecules, vol. 22, no. 11, p. 1763, 2017.

[49] M. Boncler, M. Rozalski, U. Krajewska, A. Podsedek, C. Watala, Comparison of PrestoBlue and MTT assays of cellular viability in the assessment of anti-proliferative effects of plant extracts on human endothelial cells," Journal of Pharmacological and Toxicological Methods, vol. 69, no. 1, pp. 9-16, 2014.

[50] N. F. Tanih and R. N. Ndip, "The acetone extract of Sclerocarva birrea (Anacardiaceae) possesses anti-proliferative and apoptotic potential against human breast cancer cell lines (MCF-7)," The Scientific World Journal, vol. 2013, Article ID 956206, 7 pages, 2013.

[51] S. Sireeratawong, A. Itharat, P. Khonsung, N. Lertprasertsuke, and K. Jaijoy, "Toxicity studies of the water extract from the calyces of Hibiscus sabdariffa L. in rats," African Journal of Traditional Complementary and Alternative Medicine, vol. 10, no. 4, pp. 122-127, 2013.

[52] I. J. Sagbo, M. van de Venter, T. Koekemoer, and G. Bradley, "In vitro antidiabetic activity and mechanism of action of Brachylaena elliptica (Thunb.) DC," Evidence-Based Complementary and Alternative Medicine, vol. 2018, Article ID 4170372, 13 pages, 2018.

[53] S. Chevalier, E. Bouffartigues, J. Bodilis et al., "Structure, function and regulation of Pseudomonas aeruginosa porins," FEMS Microbiology Reviews, vol. 41, no. 5, pp. 698-722, 2017.

[54] F. Pérez-Cano and M. Castell, "Flavonoids, inflammation and immune system,” Nutrients, vol. 8, no. 10, p. 659, 2016.

[55] E. A. Thiele, E. D. Marsh, J. A. French et al., "Cannabidiol in patients with seizures associated with Lennox-Gastaut syndrome (GWPCARE4): a randomized, double-blind, placebocontrolled phase 3 trial," The Lancet, vol. 18, p. 30136, 2018.

[56] M. Urrutia, J. L. Rambla, K. G. Alexiou, A. Granell, and A. Monfort, "Genetic analysis of the wild strawberry (Fragaria vesca) volatile composition," Plant Physiology and Biochemistry, vol. 121, pp. 99-117, 2017.

[57] J. C. LaManna, N. Salem, M. Puchowicz et al., "Ketones suppress brain glucose consumption," Advances in Experimental Medicine and Biology, vol. 645, pp. 301-306, 2009.

[58] A. Naz, M. S. Butt, M. T. Sultan, M. M. Qayyum, and R. S. Niaz, "Watermelon lycopene and allied health claims," EXCLI Journal, vol. 13, pp. 650-660, 2014.

[59] Y. Pan, J. Zhang, Y. L. Zhao, Y. Z. Wang, and H. Y. Huang, "Investigation of metabolites accumulation in medical plant Gentiana rigescens during different growing stage using LCMS/MS and FT-IR," Botanical Studies, vol. 56, no. 1, p. 14, 2015.

[60] C. Huimin, W. Junting, L. I. Meng et al., "Design, synthesis and in vitro biological evaluation of $1 \mathrm{H}-1,2,3$-Triazole-4carboxamide derivatives as new anti-influenza A agents targeting virus nucleoprotein," Journal of Medical Chemistry, vol. 55, pp. 2144-2153, 2012.

[61] P. Hao, I. Q. M. Alaraj, J. a. R. A. Dulayymi, M. S. Baird, J. Liu, and Q. Liu, "Sterculic acid and its analogues are potent inhibitors of Toxoplasma gondii," The Korean Journal of Parasitology, vol. 54, no. 2, pp. 139-145, 2016. 
[62] P. W. Armstrong and G. W. Moe, "Medical advances in the treatment of congestive heart failure," Circulation, vol. 88, pp. 2941-2952, 1993.

[63] M. Feldman, "Clinical characteristics of vesnarinone," Drug Safety, vol. 27, no. 1, pp. 1-9, 2004.

[64] F. Omotehara, H. Kawamata, D. Uchida et al., "Vesnarinone, a differentiation inducing drug, directly activates $p 21^{\text {wafl }}$ gene promoter via $\mathrm{Sp} 1$ sites in a human salivary gland cancer cell line," British Journal of Cancer, vol. 87, no. 9, pp. 1042-1046, 2002.

[65] F. Jubeen, S. Z. Iqbal, N. Shafiq, and M. Khan, "Co-friendly synthesis of pyrimidines and its derivatives: a review on broad spectrum bioactive moiety with huge therapeutic profile," Synthetic Communications, vol. 48, no. 6, pp. 1-25, 2018.

[66] L. M. De Castro, E. R. Kern, E. De Clercq et al., "Phosphonylmethoxyalkyl purine and pyrimidine derivatives for treatment of opportunistic cytomegalovirus and herpes simplex virus infections in murine AIDS," Antiviral Research, vol. 16, no. 1, pp. 101-114, 1991. 